\title{
Application of Nanotechnology in Targeting of Cancer Stem Cells: A Review
}

\author{
Fatemeh Asghari ${ }^{1}$, Rahele Khademi ${ }^{2}$, Faezeh Esmaeili Ranjbar ${ }^{3}$, \\ Ziba Veisi Malekshahi ${ }^{4}$, Reza Faridi Majidi ${ }^{1}$ \\ ${ }^{1}$ Department of Medical Nanotechnology, School of Advanced Technologies in Medicine, \\ Tehran University of Medical Sciences, Tehran, Iran \\ ${ }^{2}$ International affairs, School of Advanced Technologies in Medicine, Tehran University of Medical Sciences, Tehran, Iran \\ ${ }^{3}$ Department of Tissue Engineering and Applied Cell Sciences, School of Advanced Technologies in Medicine, \\ Tehran University of Medical Sciences, Tehran, Iran \\ ${ }^{4}$ Department of Medical Biotechnology, School of Advanced Technologies in Medicine, Tehran University of Medical Sciences, Tehran, Iran
}

Cancer is increasingly apparent as a systems-level, network happening. The central tendency of malignant alteration can be described as a two-phase procedure, where an initial increase of network plasticity is followed by reducing plasticity at late stages of tumor improvement. Cancer stem cells (CSCs) are cancer cells that take characteristics associated with normal stem cells. Cancer therapy has been based on the concept that most of the cancer cells have a similar ability to separate metastasise and kill the host. In this review, we addressed the use of nanotechnology in the treatment of cancer stem cells.

Keywords: Cancer stem cell, Nanomaterial, Targeting, Markers, Signaling pathway

\section{Introduction}

Progress in preclinical and clinical cancer research has brought new diagnostic and therapeutic options for cancer patients that would provide significant improvements in the treatment and prevention of cancer (1). The most lifethreatening aspect of the cancer is metastasis that spreads

Received: January 11, 2019, Revised: March 15, 2019

Accepted: April 7, 2019, Published online: June 30, 2019

Correspondence to Reza Faridi Majidi

Department of Medical Nanotechnology, School of Advanced

Technologies in Medicine, Tehran University of Medical Sciences,

Tehran 1417755469, Iran

Tel: +98-21-43052161, Fax: +98-02188991117

E-mail: refaridi@tums.ac.ir

(c) This is an open-access article distributed under the terms of the Creative Commons Attribution Non-Commercial License (http://creativecommons.org/ licenses/by-nc/4.0/), which permits unrestricted non-commercial use, distribution, and reproduction in any medium, provided the original work is properly cited.

Copyright (c) 2019 by the Korean Society for Stem Cell Research cancer cells from their original tissues to other ones (2). Cancerous tissues include collections of heterogeneous cell populations that are different in their apparent state of differentiation (3). These heterogeneous populations contain particular types of "tumor-initiating" cells arisen from mutations of normal stem cells (4). Stem cells are undifferentiated cells which were found in multi-cellular organisms. They have three main properties including differentiation, self-renewal, and homeostatic control (3). Accordingly, tumor-initiating cells were called "cancer stem cells" that have the capacity for self-renewal, being able to differentiate into any cell, and the proliferative ability to expand malignant cells (4). Although the exact cause of cancer is unknown, the understanding of the balance between self-renewal and differentiation is an essential way to prevent cancer formation and the therapeutic utilisation of stem cells in human diseases. Current cancer therapies including radiotherapy, surgery, and chemotherapy intend to destroy or kill every cell of the body (5). Cancer stem cells (CSCs) do not destroy easily with con- 
ventional methods of cancer treatment such as chemotherapy and radiation. Although, anticancer drugs can lessen tumor size, but do not kill cancer stem cells. Though CSCs might only create up a small part of a tumor, their resistance to drugs lets them persist. Therefore, the identification of tumor-initiating cancer stem cells (CSCs) is of significant interest in cancer research and suggests varied approaches (6). In the last few decades, nanotechnology and nanomaterials have found essential roles in cancer diagnosis and treatment for better early detections and also, more efficient drug delivery to the tumor cells. This review aims to highlight the opportunities and challenges for integrating the nanoscience with cancer biology and thereby, researches regarding the advanced nano-based detecting systems for cancer stem cells.

\section{Cancer Stem Cell}

Cancer is defined as a biological condition with an uncontrolled division of the natural body cells. Until now, the complete treatment of cancer as a disease is difficult and costly. One reason for this difficulty relates to the presence of specific receptors on the surface of the cancer cells that pump the drugs out of the cells. Therefore, it is difficult to find a drug to eliminate these cells. However, all cells involved in tumor development are not equally dangerous. The leading cause of cancer is a group of dividing cells with high power and high resistance to the drugs that they called CSCs. CSCs are the cells in tumors or blood that are known particularly with the ability to turn into all cell types that are found in the host body. CSCs were identified and characterized in the 1990s, when a stem cell biologist, John Dick, said that his team had isolated scarce cells in the blood of people with leukemia that seemed to have a crucial role in cancer (7). Most researchers believe that $\mathrm{CSC}$, in addition to leukemia, exists in solid tumors such as prostate, breast, and pancreas cancers. They can renew and keep themselves in the tumor masses (8-10). CSCs differentiate into several types of cells through the renewable process that can be the reason for the tumor formation. Such tumor cells as a distinct population remain and cause the disease to recur, metastasis and tumor development.

Some of the characteristics of the CSCs are similar to normal stem cells. These cells have extraordinary capability of self-renewal, differentiation and proliferative potential. The CSCs have been identified in tumor tissues and cell cultures by detecting the expressions of specific protein markers, such as CD133, CD44 and CD24 (11-13). Table 1 shows the markers of cancer stem cells in a variety of solid tumors $(6,10,12,14-31)$. The CSCs have the potential to be adapted to different environments. Therefore, the high flexibility of the CSCs can be used as a high potential for changing the plasticity and rigidity of their network (32). Environmental changes would often be strong enough for increasing the tumorigenicity of cancer stem cells (33). Generally, studies and trials have shown that the CSC self-renewal potential is determined by the high proliferative potential with a loss of regular differentiation program and high efficiency in response to environmental changes. The CSCs have two main phenotypes include the proliferative and quiescent state that characterized by symmetric and asymmetric cell divisions. The cancer stem cells with proliferative phenotypes have symmetric cell division and are less aggressive and could be classified as a plasticity network (34).

On the other hand, the CSCs with the quiescent phenotype have asymmetric cell division with dynamic properties and are classified as a rigid network (35). The CSCs with quiescent phenotype may be the main factor in the metastasis that would appear years after surgical treatment of a primary tumor. Protection of the CSCs against therapeutic agents and their resistance to the treatment process can be obtained by, quiescence, expression of $\mathrm{ABC}$ (ATP-binding cassette) drug pumps, increased expression of anti-apoptotic proteins and resistance to DNA damaging agents (Fig. 1).

It can be concluded that the tumor cells without the CSC marker would be killed by chemotherapy, resulting in tumor regression, but the cells with the CSC markers are resistant to the treatment and their number would be risen in a tumor (36-38). Surface markers of the CSC, in many types of cancers, are shown in Table 1.

The percentage of CSCs are different in many types of cancers $(39,40)$ and there are relations between the num-

Table 1. Cancer stem cell markers in a variety of solid tumors

\begin{tabular}{|c|c|c|}
\hline Type of cancers & Markers & References \\
\hline Leukemia & $\mathrm{CD}^{2} 4^{+} / \mathrm{CD} 38^{-} / \mathrm{CD} 96$ & $(10,15,16)$ \\
\hline Breast cancer & $\mathrm{CD}_{4} 4^{+} / \mathrm{ESA}^{+} / \mathrm{CD} 24^{-} / \mathrm{ALDH} 1$ & $(10,12,17)$ \\
\hline Brain cancer & $\mathrm{CD}_{133^{+}}$ & $(18,19)$ \\
\hline Multiple myelomas & $\mathrm{CD}_{138}^{-}$ & $(20,21)$ \\
\hline Pancreatic cancer & $\mathrm{CD} 44^{+} / \mathrm{CD} 24^{+} / \mathrm{ESA}^{+}$ & $(6,22)$ \\
\hline Colon cancer & $\mathrm{CD}_{133^{+}}$ & (23) \\
\hline Liver cancer & $\mathrm{CD} 33^{+} / \mathrm{CD} 0^{+}$ & $(24,25)$ \\
\hline Prostate cancer & $\mathrm{CD}_{4} 4^{+} / \mathrm{CD} 133^{+}$ & $(26,27)$ \\
\hline Lung cancer & $\mathrm{CD}_{133^{+}}$ & (28) \\
\hline Ovarian cancer & $\begin{array}{l}\mathrm{CD} 133^{+} / \mathrm{CD} 44^{+} / \mathrm{CD} 117^{+} / \\
\mathrm{CD} 24^{+}\end{array}$ & $(29-31)$ \\
\hline
\end{tabular}


ber of CSCs and patient prognosis $(41,42)$. Studies have demonstrated that cancer therapy could target the tumor cell mass and create a partial regression of a tumor, but the CSCs could make and develop new tumor clones, therefore, identification and directed targeting against this kind of stem cells have been reported to be more effective (Fig. 2) (40, 43). Cancer therapy, based on this hypothesis, was reported to decrease mechanisms of resistance to conventional chemotherapeutic drugs and radiation therapy. The new design of cancer therapeutic drugs could eliminate the CSCs by interfering with the specific pathways (44-48).

Scientists and researchers have suggested that comprehension of disorders in signal pathways or too much activation is one of the most vital importance for anticancer targeting of the CSCs. Wnt, Notch and Hedgehog signaling pathways have critical roles in the reappearance and maintenance of cancer stem cells (49). Wnt marks a group of signaling proteins that bind to surface receptor molecules on the target cells. Activation of Wnt target genes happens by $\beta$-Catenin. Also activated Wnt/ $\beta$-Catenin signaling has been reported to be a key feature of epithelial cancers, epithelial-mesenchymal transition (EMT), and maintenance of the CSCs of melanoma, breast, colon, liver and lung cancers (50).

Notch signaling pathway has a critical role in the cell-fate decision, tissue patterning, morphogenesis (51), and maintenance of the glioblastoma and breast cancer stem cells (52). A reported study about Notch signaling

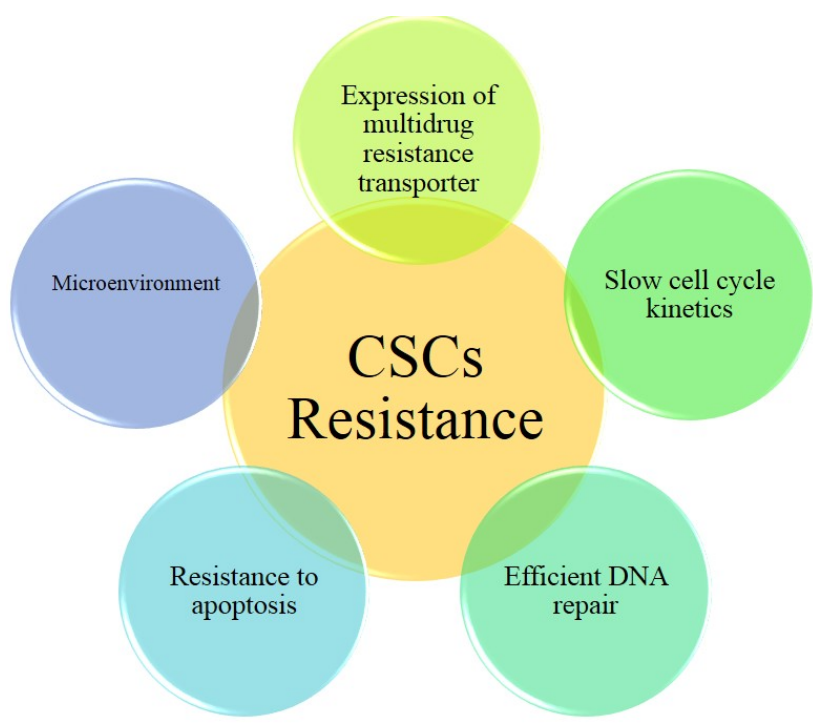

Fig. 1. CSCs resistance to treatment can be obtained by, expression of $\mathrm{ABC}$ drug pumps, increased expression of anti-apoptotic proteins, resistance to DNA damaging agents, and slow cycle kinetics. pathway suggested that Notch inhibition in glioblastoma could decrease cancer stem cells via an endothelial cell intermediate (53).

Studies have suggested that the Hedgehog (Hh) signaling can regulate many cancer stem cells including glioblastoma, pancreatic adenocarcinoma, breast cancer, multiple myeloma, and chronic myeloid leukemia (CML) (20). Hh signaling has been found to play multiple roles in development, homeostasis and disease by activating the 7-pass transmembrane protein Smoothened (Smo), to send an intracellular signal. Due to that, the most advanced types of Hh antagonists are Smo-targeted (54, 55). Targeting the signal pathways including the Wnt, Notch, and Hh may improve current strategies for cancer therapy. Although, anti-cancer treatment can reduce tumor size, survived CSCs would trigger tumor formation again. This type of relapse causes metastasis and more resistant to treatment. Therefore, most currently available cancer treatments such as hormone therapy, radiotherapy and chemotherapy, would not be useful in the elimination of cancer stem cells (5). Specific targeting of tumor stem cells has been suggested to be an efficient alternative for cancer treatment $(10,11)$.

\section{Cancer Treatment with Nanotechnology}

Today, cancer mortality is one of the most common causes of death. The application of nanotechnology in

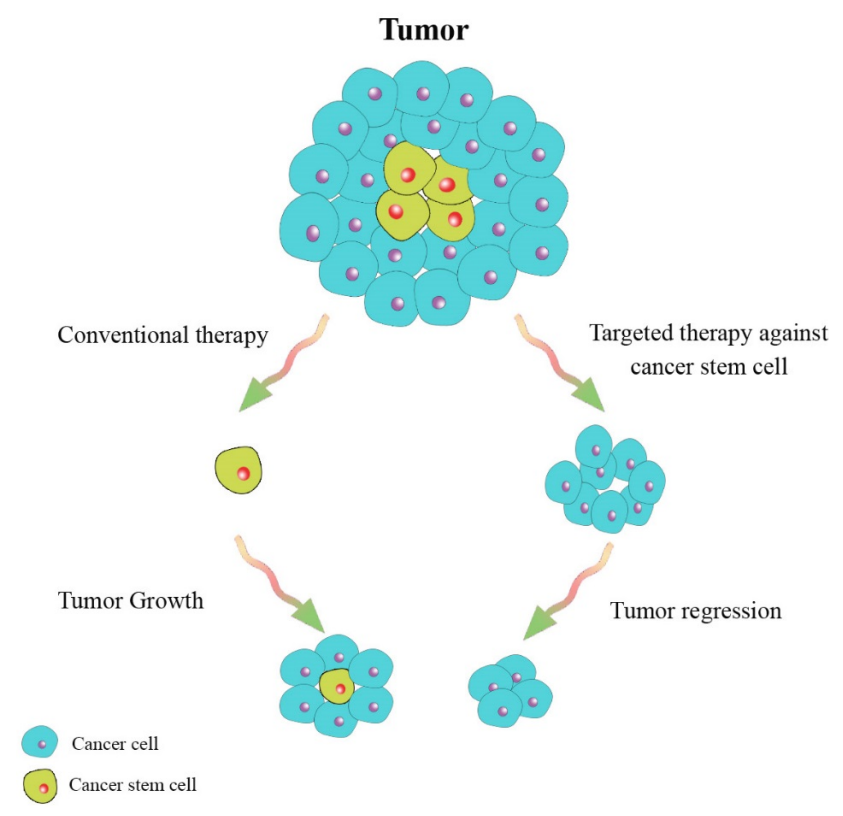

Fig. 2. A schematic illustration showing targeted therapy against cancer stem cells and tumors bulk. 
medicine includes six areas including 1) detection of molecular changes in diseases; 2) diagnosis and imaging; 3) drug delivery; 4) combined therapeutic and diagnostic applications; 5) report of therapeutic agent efficacy; and 6) nanotechnology applications in scientific discovery and basic research (56). A variety of nanostructures from organic and inorganic materials have been recently used for cancer therapy and diagnosis in passive or active tumor targeting. A novel formulation of nanovesicles, liposomes, polymeric micelles, dendrimers, and polymeric nanoparticles can enter into the solid tumor site through the porous structure of a tumor vascular system, and then, selectively deliver the therapeutic agents $(57,58)$. Nanomaterials with proper targeting ligands could bind to antigens or receptors on the target cells. However, this powerful technology leads to a decreased toxicity in non-targeted cells, and therefore, the distribution of nanomaterials will be increased in the target cells (59). Some of the nanomaterials shown in Table 2 (60-73) such as semiconducting nanoparticles or quantum dots (QDs), colloidal nanoparticles, dendrimers, magnetic nanoparticles (MNPs), carbon-based nanomaterials (CBNs), and liposomal nanoparticles systems have been constructed for utilization in therapeutic applications. Quantum dots (QDs) are semiconducting nanoparticles with the diameter ranging from $2 \sim 10 \mathrm{~nm}$, narrow emission and broad absorption profile, high photostability, long fluorescence lifespan, ability to be conjugated with proteins (74). Also, QDs have the potential of applications in molecular and cellular labelling, cell tracking, drug delivery and also, cancer detection and therapy $(75,76)$. Dendrimers are highly branched synthetic polymers (about $1.5 \sim 13.5 \mathrm{~nm}$ ) $(77,78)$ that have attracted considerable attention because of their hyper-branched structure, monodispersity, functional surface groups, and symmetrical conformation (79).

Furthermore, they have various types of core molecules, such as ethylenediamine, cysteamine, diaminobutane, carbohydrate, calixarene, etc. and functional surface groups like amino, carboxyl, hydroxyl that give the opportunity to modify their surfaces with biomolecules (80). Polyamidoamines (PAMAMs) are the most widely studied dendrimer because of the polycationic properties that can have interaction with charged molecules (81). Gold nanoparticles (GNPs), with diameter size of 0.8 to $200 \mathrm{~nm}$ have been used for imaging, targeting, drug delivery, and therapy applications. Biological molecules can be readily attached to the surfaces of the GNPs. Binding of molecules including biotin, peptides or oligonucleotides enhances cell penetration efficiency of the nanoparticles. Surface plasmon resonance of GNPs is used to many applications such as hyperthermia (82). Superparamagnetic NPs (SPIONs) are small synthetic particles of iron oxides with a core size of $0 \sim 10 \mathrm{~nm}$. They show new magnetization behaviour totally like standard paramagnetic materials, but with, high field irreversibility, high saturation field, additional anisotropy contributions or shifted loops after field cooling (83, 84). Also, after eliminating the magnetic field, they do not show magnetic interactions (85). The SPIONs well-dispersed in a liquid and especially in water have drastically increased their biological and medical applications in recent years. Applications of SPIONs are diagnosis, therapy, and drug delivery system; Moreover, recent systems are

Table 2. Various nanomaterials for therapeutic applications

\begin{tabular}{lllc}
\hline \multicolumn{1}{c}{ Nanomaterial } & \multicolumn{1}{c}{ Ligand } & Target & $\begin{array}{c}\text { Refe- } \\
\text { rences }\end{array}$ \\
\hline Quantum dot & HER2/neusiRNA & SKBR3 & $(60)$ \\
Quantum dot/Chitosan & DNA aptamer & A2780/AD & $(61)$ \\
Quantum dot & HER2; RNase A & MGC-803 & $(62)$ \\
PAMAM & Tf and Tm & glioma Dual-targeting & $(63)$ \\
PAMAM & Biotin & HeLa & $(64)$ \\
SPIONs- $\alpha$ v $\beta 3$ & Anti $\alpha$ v antibody RGD peptides & $\alpha$ V $\beta 3$ Integrin Breast cancer & $(65)$ \\
SPIONs-PEG-Ab & Monoclonal Ab A7 & Colorectal carcinoma & $(66)$ \\
Gold nanoparticle & Folic acid & Ovarian cancer & $(67)$ \\
Gold nanoparticle & Bombesinpeptides & Human prostate cancer cells & $(68)$ \\
Gold nanoparticle & Transferrin & Hs578T (breast cancer) and a nonmalignant cell lines (3T3) & $(69)$ \\
MWCNT & Folate (biologically active targeting) and & HeLa & $(70)$ \\
& iron (magnetically passive) targeting & & \\
SWCNT & Hyaluronic acid Salinomycin Gastric & cancer stem cells (CSCs) & $(71)$ \\
Graphene oxide & Rituxan (CD201 antibody) & CEM.NK T-cell and Raji B-cell & $(72)$ \\
Nanoliposome & Anti-HER2 & HER2- overexpressing breast cancer & $(73)$ \\
\hline
\end{tabular}


used on stem cell differentiating/tracking $(85,86)$. Carbonbased nanomaterials (CBNs) are one of the most widely used tools in the fields of biomedicine, biotechnology, environment, and electronics $(87,88)$. CBNs with excellent physical, mechanical, electronic, and biological properties are engineered by using graphite, in different types of graphene, fullerene, and single- or multi-walled CNTs (89). Besides, modification of CBNs with biomaterials have been utilized in imaging, delivery systems, targeted therapy, tissue scaffold reinforcements, and bio-detection systems (90). Liposomes, as the most clinically established nano-scaled platforms, are merely formed from phospholipids and cholesterol by a self-assembling method in aqueous media in a variable size distribution from $20 \sim 1000$ $\mathrm{nm}$ (91). The most application of liposomes is in drug delivery systems in which encapsulated drugs could be protected and directly delivered to the cells within lipid bilayers (92). Fig. 3 demonstrates the various nanomaterial that targeted cancer stem cells.

\section{Targeting Cancer Stem Cells with Nanomaterials}

The CSCs are believed to drive tumor growth and be highly resistant to conventional therapies (e.g. chemotherapy and radiotherapy) and lead to disease relapse and the formation of metastases. Therefore, there is consid- erable interest in the use of nano-sized materials for CSCdirected anti-cancer therapies. The surface of nanoparticles has been designed to accurately and effectively target the CSCs (93). Identification of the CSC is possible by some markers, e.g. ALDH, CD44, CD90, and CD133, and specific signaling pathways, i.e. Notch, Hedgehog and transforming growth factor- $\beta$ (TGF- $\beta$ ) $(94,95)$ to improve the treatment strategies and therapeutic outcomes (96).

\section{Aldehyde Dehydrogenases (ALDH) marker}

Aldehyde Dehydrogenases (ALDH) is a functional marker of the CSCs and also, the scavenger of reactive oxygen species (ROS) (97-99). Studies have been demonstrated that ALDH activity of converting retinol to retinoic acid increases in many cancers $(100,101)$, such as cervical cancer (102), non-small cell lung cancer (103), melanoma (104), and also is considered as a specific marker of BCSCs in breast cancer (105). Disulfiram (DS), is a specific inhibitor of the ALDH that have cytotoxic effects on a wide range of cancer cell lines including colon, breast and brain ones (106-112). However, its clinical application is limited due to very short half-life in the bloodstream. A study revealed that encapsulation of the by poly (lactic-co-glycolic) acid (PLGA) nanoparticles (DS-PLGA) causes longer circulating time in the blood-
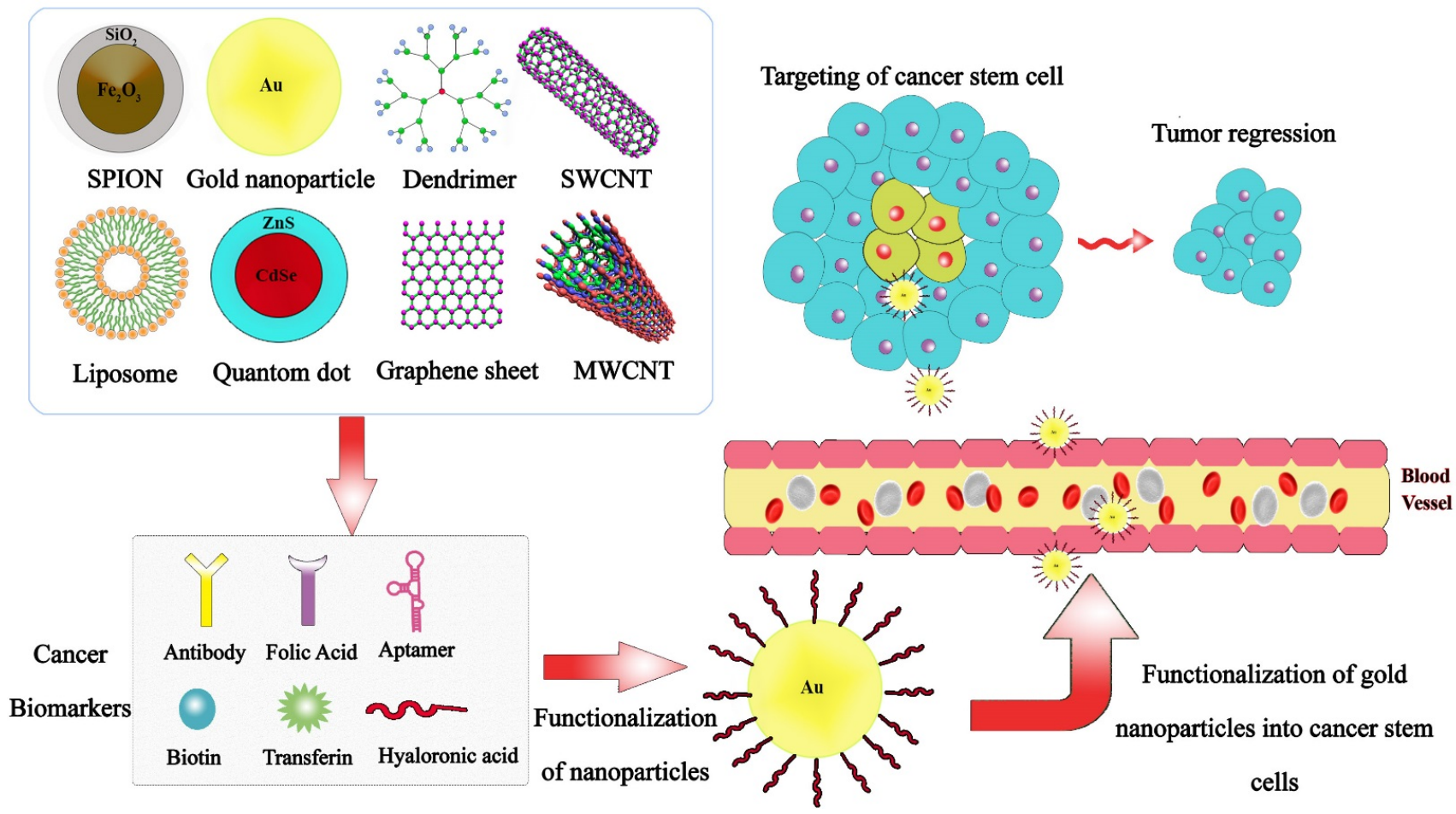

Fig. 3. The schematic representation of targeting cancer stem cell via functionalized nanomaterial. 
stream, and also, DS-PLGA/Cu combination manifests very likely synergistic cytotoxicity effect with 5 -FU and sorafenib. Finally, the results suggest that nano-based controlled delivery system would make DS fast translation into liver cancer cells (97).

\section{CD44 factor}

CD44 factor is one of the most popular and familiar surface biomarkers associated with cancer stem cells (113). Clinical studies have demonstrated the CD44 as one of the most critical proteins in tumor genesis, growth, metastasis, and chemo-resistant processes in a verity of tumors in colon, breast, head and neck, and pancreatic cancers cancers (26, 114, 115). Antibody-based cancer treatments, overexpressing CD44, represents the dominant anti-CSC approach specifically in BCSCs (116). In a study, active targeting and drug delivery to the breast and colon cancer cell lines was evaluated by biodegradable poly[(D, L-lactide co-glycolide)-co-PEG] (PDLGA-co-PEG) polymeric micelles loaded with paclitaxel (PTX) and functionalized with anti-CD44 antibodies. Evidence has shown that active-targeted PLGA-co-PEG-PTX micelles increase the intracellular concentration of PTX, and therefore, the effectiveness of drug delivery to the CSC (117). Arabi et al. (118) have demonstrated the selective drug delivery potential of liposomal doxorubicin functionalized with anti-CD44 and increased circulation time, biodistribution and therapeutic efficacies of CD44-Doxil compared to the non-targeted liposomal formulation and free drug. Magnetic NPs (MNPs) with anti-CD44 antibody have also shown the potential selective treatment of CD44 positive cancers such as pancreatic and breast cancers cell lines (119).

\section{CD133 Marker}

As mentioned before, the CSCs can be identified by detection of the CD133 expression as a stem cell marker and also, is explicitly regarded as a marker in osteosarcoma. The potential of CD133 targeting for drug delivery to the CSCs in osteosarcoma has been examined previously. It is illustrated in a study that Poly (lactic-co-glycolic acid) nanoparticles conjugated with CD133 aptamers would deliver salinomycin specifically and efficiently to the $\mathrm{CD} 133^{+}$ CSCs in osteosarcoma and kill them (120). In another new form of drug nanocarrier, mesoporous silica nanoparticles (MSNs) have been used to deliver both antitumor drugs and siRNA into $\mathrm{CD}_{133^{+}}$cancer cells. This formulation significantly improved the efficacy of therapeutic drugs in laryngeal cancer cells (121). Curcumin and some other natural chemopreventive agents have recently been shown to inhibit the CSCs, but with low bioavailability.

Furthermore, various nanotechnology-based formulations of curcumin have been recently evaluated as well. Preparation of the nanoscale drug delivery systems has been considered as an innovative approach to overcome the bioavailability and stability issues. For instance, it has been shown that a polymeric nanoparticle (made by mixing $\mathrm{N}$-isopropylacrylamide, vinylpyrrolidone, and acrylic acid in a molar ratio of $60: 20: 20$ ) encapsulating curcumin, named "nanocurcumin", can inhibit brain tumor cell growth and deplete $\mathrm{CD}_{133^{+}}$stem-like cells $(122,123)$.

\section{Notch Signaling Pathway}

Another major pathway involved in the CSC regulation isNotch signaling pathway that controls cell-fate determination during development and maintains adult tissue homeostasis (124). This pathway could lead to the development of many cancers including melanoma, medulloblastoma, rhabdomyosarcoma, basal cell carcinoma, breast, lung, liver, pancreas, and prostate cancers (125). Fan et al. (126) examined the effects of Notch pathway inhibition on the growth and xenograft formation of medulloblastoma. They found that Notch blockade results in the growth of tumor cells and tumor-forming capacity, due to the depletion of stem-like cells. Clinical application of Notch inhibitors, $\gamma$-secretase inhibitors (GSIs), is restricted by severe side effects. Imagable mesoporous silica nanoparticles (MSNPs) have been developed as vehicles for targeted delivery of GSIs to block Notch signaling. GSI-loaded on biocompatible and biodegradable MSNPs enhanced therapeutic efficacy in tumor reduction and regulation of Notch driven stem cell fates (127). Specific functionalization of nanoparticles could be used to enhance targetability to specific cell populations. Mamaeva et al. (128) have demonstrated that breast CSCs display enhanced glucose uptake compared to normal breast cancer cells. This specific feature of the breast CSCs has been utilized to design functionalized mesoporous silica nanoparticles (MSNs). The MSNs were functionalized with glucose analogues to deliver Notch signaling inhibitors to the CSCs efficiently. The results have demonstrated a reduction in the CSC pool and suppression of tumor growth in vitro and in vivo.

\section{90}

CD90 is glycosylphosphatidylinositol (GPI) anchored glycoprotein that is expressed in leukocytes, bone mar- 
row-derived mesenchymal stem cells, hepatic stem/progenitor cells (HSPCs) and also, is identified in murine breast CSCs. Studies have shown that $\mathrm{CD}^{+} 0^{+}$cells have tumorigenicity and metastatic potential (129). 90\% of blood samples from liver cancer patients contained $\mathrm{CD}^{-} 5^{-} /$ $\mathrm{CD}^{+} 0^{+}$markers (25). Bakalova et al. (130) have utilized CD90 as a valid therapeutic target They have shown that photosensitizer trifluoperazine loaded in anti-CD90 antibody-mediated water-soluble CdSe core nanocrystals could be delivered directly to the $\mathrm{CD} 90^{+}$leukemia CSCswhereit could cause leukemia CSCs sensitivity to UV irradiation and apoptotic cell death.

\section{Hedgehog (Hh) Signaling Pathway}

It is known that the Hh pathway helps in controlling cell growth and morphogenesis. The components of the Hh signal transduction pathway can control embryonic development and also, is expressed in postnatal and adult tissues. These components have assigned roles in the maintenance of stem cells and tissue repair (131). At least three Hh gene homologs have been identified in human: Sonic Hh (SHh), Desert Hh (Dhh), and Indian Hh (Ihh), among which SHh is the most widely used one (132). Hh ligand can bind to the 12-transmembrane receptor Patched 1, which relieves seven-pass transmembrane receptor named Smoothened (Smo) from repression and allows downstream activation of the pathway through the translocation of GLI, where it acts as a transcription factor to the nucleus with the mediation of SUFU and KIF17. High expression and aberrant activation of Hh ligands present in the majority of human cancers including brain tumors, melanomas, leukemia's, gastrointestinal, malignancies of the breast, ovary, prostate and, pancreas cancers (133). Therefore, targeting the Hh signaling pathway may provide a practical therapeutic approach in the treatment of various cancers. GLI inhibition through PLGA-PEG nanoparticles (NanoHHI) has illustrated tumor growth inhibition and antimetastatic effects in hepatocellular carcinoma (HCC) models $(134,135)$. In another study, the effects of anthothecol-encapsulated PLGA-nanoparticles (Antho-NPs) have been examined on the behaviour of pancreatic cancer stem cells (CSCs). They have discovered that Antho-NPs inhibited the CSC proliferation and induced apoptosis by disrupting GLI-DNA binding and also, it acts as GLIinhibitor. Using PLGA nanoparticles offers many benefits of appropriate stability in physiological environments, entering to a cancerous sphere without any auxiliary reagents, loss of toxicity towards human pancreatic normal cells and PLGA-NPs could cross the blood-tu- mor barrier (136).

\section{Transforming Growth Factor- $\beta$ (TGF- $\beta$ )}

TGF- $\beta$ signaling is an important prognostic marker in various types of cancers including breast (137), colon (138), liver (139), lung (140) and ovary tumors (141). Also, its potential role in the CSCs has been recently reported in breast (142), colon (143), liver (144), and lung (145), cancers. Thus, selective targeting of TGF- $\beta$ signaling would significantly improve therapeutic efficiency in tumor models (146). For breast cancer treatment, polyethyleneimine/polyethylene glycol-conjugated MSNPs were developed to load LY364947 as a TGF- $\beta$ inhibitor (146). These polymeric nanoparticles and inhibition of TNF- $\beta$ signaling pathway have been used in the delivery of siRNA to the breast CSCs. Nanoparticles could be accumulated in tumors that in turn, increases siRNA concentrations in tumor tissues and notably, lower the proportions of the CSCs (147). Gold NPs (AuNPs) with much application in therapeutic and diagnostic agents could selectively deactivate the TGF- $\beta$ signaling pathway. Tsai et al. have found that AuNPs could attenuate the immunosuppressive function of TGF- $\beta_{1} \beta$ signaling pathway and also, increase the number and frequency of tumor-infiltrating $\mathrm{T}$ lymphocytes (148).

\section{Prospects}

The cancer treatment needs the improvement of approaches which can efficiently eliminate cancer and amend the application of this novel drug-delivery modality (nanomedicines) $(149,150)$. Recently, researchers have been interested in the nanotechnology-based drug because these drugs are most useful for developing anti-cancer therapies and CSCs targeting. There is some clinically approved nanomedicine include Pegylated liposome (Doxil), Albumin-bound paclitaxel particles (Abraxane), Iron oxide nanoparticles (NanoTherm), PEG-1 Asparaginase (Oncaspar), Methoxy-PEG-poly (d,1-lactide)- paclitaxel micelle (Genexol -PM) and SMANCS (Zinostatin) (151). Considering these issues that mentioned the nanotechnology-based anticancer drug helps treat and prevent various types of cancers because these drugs have excellent diffusion capacity, selective killing of tumor cells or CSCs. Also, CSC-targeting with nanomaterials is in the early stages because these studies have done in vitro and in vitro phase only. So a vast amount of detail in vitro, in vivo and other relevant information, is essential that these nanomedicine products have a clinical practice. The other important issues are the 
safety, effective dosages and side effects of nanomaterials used in drug delivery systems which should be given special attention (152).

Finally, the most important thing is that the treatment of cancer using nanotechnology is helpful approaches for cancer patients because most of them suffer from chemotherapy and radiotherapy. Moreover, CSCs targeting with nanomaterial may present a novel method for reducing the costs on the public health care system.

\section{Conclusions}

The basic cause of cancer is a group of dividing cells with high power and high resistance to the drugs that they called Cancer Stem Cells (CSCs). CSCs were identified an characterized in the 1990s, in the blood of people with leukemia that seemed to have a vital role in cancer. CSCs are markedly resistant to conventional cancer treatments, such as chemotherapy and radiation. Therefore, understanding tumor biology is critical for the development of successful therapies. Identifying and selectively targeting markers and signaling pathways of CSCs are new therapeutic strategies for cancer treatment. The current success in the fight against CSCs has been reported in studies that using nanotechnology-based therapeutics with using different surface markers and biochemical assays for identification. Based on nanomedicine studies mentioned in our review, it is shown that nanomedicine in the treatment of CSCs can provide additional benefits for cancer patients with fewer drugs side effects such as, increasing their cellular uptake, prolonging systemic circulation, improving biodistribution profiles, and resolving problems of poor stability and solubility. This review has shown bright prospects of cancer treatment by nanomaterials, and specifically nanoparticles with increased therapeutic potency in drug delivery, CSC specificity and fewer side effects.

\section{Acknowledgments}

The authors thank the Department of Medical Nanotechnology, School of Advanced Technologies in Medicine, Tehran University of Medical Sciences for all the support provided.

\section{Potential Conflict of Interest}

The authors have no conflicting financial interest.

\section{References}

1. Siegel R, Naishadham D, Jemal A. Cancer statistics, 2013. CA Cancer J Clin 2013;63:11-30
2. Sahai E. Mechanisms of cancer cell invasion. Curr Opin Genet Dev 2005;15:87-96

3. Dalerba P, Cho RW, Clarke MF. Cancer stem cells: models and concepts. Annu Rev Med 2007;58:267-284

4. Jordan CT, Guzman ML, Noble M. Cancer stem cells. N Engl J Med 2006;355:1253-1261

5. World Health Organization. WHO handbook for reporting results of cancer treatment. Geneva: WHO; 1979.

6. Li C, Heidt DG, Dalerba P, Burant CF, Zhang L, Adsay $\mathrm{V}$, Wicha M, Clarke MF, Simeone DM. Identification of pancreatic cancer stem cells. Cancer Res 2007;67:1030-1037

7. Bonnet D, Dick JE. Human acute myeloid leukemia is organized as a hierarchy that originates from a primitive hematopoietic cell. Nat Med 1997;3:730-737

8. Ciurea ME, Georgescu AM, Purcaru SO, Artene SA, Emami GH, Boldeanu MV, Tache DE, Dricu A. Cancer stem cells: biological functions and therapeutically targeting. Int J Mol Sci 2014;15:8169-8185

9. Castelo-Branco P, Zhang C, Lipman T, Fujitani $M$, Hansford L, Clarke I, Harley CB, Tressler R, Malkin D, Walker E, Kaplan DR, Dirks P, Tabori U. Neural tumor-initiating cells have distinct telomere maintenance and can be safely targeted for telomerase inhibition. Clin Cancer Res 2011;17:111-121

10. Li C, Hynes MJ, Jing J. Pancreatic cancer stem cells: new direction for pancreatic cancer treatment. Trends Bio/ Pharm Ind 2010;6:34-40

11. Miki J, Furusato B, Li H, Gu Y, Takahashi H, Egawa S, Sesterhenn IA, McLeod DG, Srivastava S, Rhim JS. Identification of putative stem cell markers, CD133 and CXCR4, in hTERT-immortalized primary nonmalignant and malignant tumor-derived human prostate epithelial cell lines and in prostate cancer specimens. Cancer Res 2007;67:3153-3161

12. Ricardo S, Vieira AF, Gerhard R, Leitão D, Pinto R, Cameselle-Teijeiro JF, Milanezi F, Schmitt F, Paredes J. Breast cancer stem cell markers CD44, CD24 and ALDH1: expression distribution within intrinsic molecular subtype. J Clin Pathol 2011;64:937-946

13. Takaishi S, Okumura T, Tu S, Wang SS, Shibata W, Vigneshwaran R, Gordon SA, Shimada Y, Wang TC. Identification of gastric cancer stem cells using the cell surface marker CD44. Stem Cells 2009;27:1006-1020

14. Burnett J. The natural product sulforaphane inhibits breast cancer stem cell targets in triple negative and trastuzumab-resistant breast cancers [PhD dissertation]. Michigan: University of Michigan; 2015.

15. Wang JC, Dick JE. Cancer stem cells: lessons from leukemia. Trends Cell Biol 2005;15:494-501

16. Hosen N, Park CY, Tatsumi N, Oji Y, Sugiyama H, Gramatzki M, Krensky AM, Weissman IL. CD96 is a leukemic stem cell-specific marker in human acute myeloid leukemia. Proc Natl Acad Sci U S A 2007;104:11008-11013

17. Croker AK, Goodale D, Chu J, Postenka C, Hedley BD, Hess DA, Allan AL. High aldehyde dehydrogenase and expression of cancer stem cell markers selects for breast can- 
cer cells with enhanced malignant and metastatic ability. J Cell Mol Med 2009;13:2236-2252

18. Beier D, Hau P, Proescholdt M, Lohmeier A, Wischhusen J, Oefner PJ, Aigner L, Brawanski A, Bogdahn U, Beier CP. CD133(+) and CD133(-) glioblastoma-derived cancer stem cells show differential growth characteristics and molecular profiles. Cancer Res 2007;67:4010-4015

19. Singh SK, Clarke ID, Terasaki M, Bonn VE, Hawkins C, Squire J, Dirks PB. Identification of a cancer stem cell in human brain tumors. Cancer Res 2003;63:5821-5828

20. Peacock CD, Wang Q, Gesell GS, Corcoran-Schwartz IM, Jones E, Kim J, Devereux WL, Rhodes JT, Huff CA, Beachy PA, Watkins DN, Matsui W. Hedgehog signaling maintains a tumor stem cell compartment in multiple myeloma. Proc Natl Acad Sci U S A 2007;104:4048-4053

21. Dammacco F, Leone P, Silvestris F, Racanelli V, Vacca A. Cancer stem cells in multiple myeloma and the development of novel therapeutic strategies. In: Dammacco F, editor. Oncogenomics. London: Elsevier; 2019. 121-137

22. Hermann PC, Huber SL, Herrler T, Aicher A, Ellwart JW, Guba M, Bruns CJ, Heeschen C. Distinct populations of cancer stem cells determine tumor growth and metastatic activity in human pancreatic cancer. Cell Stem Cell 2007; 1:313-323

23. Vermeulen L, De Sousa E Melo F, van der Heijden M, Cameron K, de Jong JH, Borovski T, Tuynman JB, Todaro M, Merz C, Rodermond H, Sprick MR, Kemper K, Richel DJ, Stassi G, Medema JP. Wnt activity defines colon cancer stem cells and is regulated by the microenvironment. Nat Cell Biol 2010;12:468-476

24. Ma S, Chan KW, Hu L, Lee TK, Wo JY, Ng IO, Zheng $\mathrm{BJ}$, Guan XY. Identification and characterization of tumorigenic liver cancer stem/progenitor cells. Gastroenterology 2007;132:2542-2556

25. Yang ZF, Ho DW, Ng MN, Lau CK, Yu WC, Ngai P, Chu PW, Lam CT, Poon RT, Fan ST. Significance of CD90+ cancer stem cells in human liver cancer. Cancer Cell 2008;13:153-166

26. Collins AT, Berry PA, Hyde C, Stower MJ, Maitland NJ. Prospective identification of tumorigenic prostate cancer stem cells. Cancer Res 2005;65:10946-10951

27. Liu C, Kelnar K, Liu B, Chen X, Calhoun-Davis T, Li H, Patrawala L, Yan H, Jeter C, Honorio S, Wiggins JF, Bader AG, Fagin R, Brown D, Tang DG. The microRNA miR-34a inhibits prostate cancer stem cells and metastasis by directly repressing CD44. Nat Med 2011;17:211-215

28. Eramo A, Lotti F, Sette G, Pilozzi E, Biffoni M, Di Virgilio A, Conticello C, Ruco L, Peschle C, De Maria R. Identification and expansion of the tumorigenic lung cancer stem cell population. Cell Death Differ 2008;15:504514

29. Gao MQ, Choi YP, Kang S, Youn JH, Cho NH. CD24+ cells from hierarchically organized ovarian cancer are enriched in cancer stem cells. Oncogene 2010;29:2672-2680

30. Silva IA, Bai S, McLean K, Yang K, Griffith K, Thomas D, Ginestier C, Johnston C, Kueck A, Reynolds RK, Wicha
MS, Buckanovich RJ. Aldehyde dehydrogenase in combination with CD133 defines angiogenic ovarian cancer stem cells that portend poor patient survival. Cancer Res 2011; 71:3991-4001

31. Zhang S, Balch C, Chan MW, Lai HC, Matei D, Schilder JM, Yan PS, Huang TH, Nephew KP. Identification and characterization of ovarian cancer-initiating cells from primary human tumors. Cancer Res 2008;68:4311-4320

32. Csermely P, Hódsági J, Korcsmáros T, Módos D, PerezLopez ÁR, Szalay K, Veres DV, Lenti K, Wu LY, Zhang XS. Cancer stem cells display extremely large evolvability: alternating plastic and rigid networks as a potential mechanism: network models, novel therapeutic target strategies, and the contributions of hypoxia, inflammation and cellular senescence. Semin Cancer Biol 2015;30:42-51

33. Liu L, Rando TA. Manifestations and mechanisms of stem cell aging. J Cell Biol 2011;193:257-266

34. Hoek KS, Goding CR. Cancer stem cells versus phenotype-switching in melanoma. Pigment Cell Melanoma Res 2010;23:746-759

35. Visvader JE, Lindeman GJ. Cancer stem cells in solid tumours: accumulating evidence and unresolved questions. Nat Rev Cancer 2008;8:755-768

36. Singh A, Settleman J. EMT, cancer stem cells and drug resistance: an emerging axis of evil in the war on cancer. Oncogene 2010;29:4741-4751

37. Fletcher JI, Haber M, Henderson MJ, Norris MD. ABC transporters in cancer: more than just drug efflux pumps. Nat Rev Cancer 2010;10:147-156

38. Gottesman MM. Mechanisms of cancer drug resistance. Annu Rev Med 2002;53:615-627

39. Quintana E, Shackleton M, Sabel MS, Fullen DR, Johnson TM, Morrison SJ. Efficient tumour formation by single human melanoma cells. Nature 2008;456:593-598

40. Cho RW, Clarke MF. Recent advances in cancer stem cells. Curr Opin Genet Dev 2008;18:48-53

41. Bloushtain-Qimron N, Yao J, Snyder EL, Shipitsin M, Campbell LL, Mani SA, Hu M, Chen H, Ustyansky V, Antosiewicz JE, Argani P, Halushka MK, Thomson JA, Pharoah P, Porgador A, Sukumar S, Parsons R, Richardson AL, Stampfer MR, Gelman RS, Nikolskaya T, Nikolsky Y, Polyak K. Cell type-specific DNA methylation patterns in the human breast. Proc Natl Acad Sci U S A 2008;105:14076-14081

42. Shipitsin M, Campbell LL, Argani P, Weremowicz S, Bloushtain-Qimron N, Yao J, Nikolskaya T, Serebryiskaya T, Beroukhim R, Hu M, Halushka MK, Sukumar S, Parker LM, Anderson KS, Harris LN, Garber JE, Richardson AL, Schnitt SJ, Nikolsky Y, Gelman RS, Polyak K. Molecular definition of breast tumor heterogeneity. Cancer Cell 2007; 11:259-273

43. Dick JE. Looking ahead in cancer stem cell research. Nat Biotechnol 2009;27:44-46

44. Moitra K, Lou H, Dean M. Multidrug efflux pumps and cancer stem cells: insights into multidrug resistance and therapeutic development. Clin Pharmacol Ther 2011;89: 
491-502

45. Vermeulen L, de Sousa e Melo F, Richel DJ, Medema JP. The developing cancer stem-cell model: clinical challenges and opportunities. Lancet Oncol 2012;13:e83-e89

46. Zhou BB, Zhang H, Damelin M, Geles KG, Grindley JC, Dirks PB. Tumour-initiating cells: challenges and opportunities for anticancer drug discovery. Nat Rev Drug Discov 2009;8:806-823

47. Naujokat C, Steinhart R. Salinomycin as a drug for targeting human cancer stem cells. J Biomed Biotechnol 2012; 2012:950658

48. Domingo-Domenech J, Vidal SJ, Rodriguez-Bravo V, Castillo-Martin M, Quinn SA, Rodriguez-Barrueco R, Bonal DM, Charytonowicz E, Gladoun N, de la IglesiaVicente J, Petrylak DP, Benson MC, Silva JM, CordonCardo C. Suppression of acquired docetaxel resistance in prostate cancer through depletion of notch- and hedgehog-dependent tumor-initiating cells. Cancer Cell 2012;22: 373-388

49. Hu Y, Fu L. Targeting cancer stem cells: a new therapy to cure cancer patients. Am J Cancer Res 2012;2:340-356

50. Zhao C, Blum J, Chen A, Kwon HY, Jung SH, Cook JM, Lagoo A, Reya T. Loss of beta-catenin impairs the renewal of normal and CML stem cells in vivo. Cancer Cell 2007; 12:528-541

51. Yin L, Velazquez OC, Liu ZJ. Notch signaling: emerging molecular targets for cancer therapy. Biochem Pharmacol 2010;80:690-701

52. Guo S, Liu M, Gonzalez-Perez RR. Role of Notch and its oncogenic signaling crosstalk in breast cancer. Biochim Biophys Acta 2011;1815:197-213

53. Hovinga KE, Shimizu F, Wang R, Panagiotakos G, Van Der Heijden M, Moayedpardazi H, Correia AS, Soulet D, Major T, Menon J, Tabar V. Inhibition of notch signaling in glioblastoma targets cancer stem cells via an endothelial cell intermediate. Stem Cells 2010;28:1019-1029

54. Peukert S, Miller-Moslin K. Small-molecule inhibitors of the hedgehog signaling pathway as cancer therapeutics. ChemMedChem 2010;5:500-512

55. Chen JK, Taipale J, Cooper MK, Beachy PA. Inhibition of Hedgehog signaling by direct binding of cyclopamine to Smoothened. Genes Dev 2002;16:2743-2748

56. Alexis F, Rhee JW, Richie JP, Radovic-Moreno AF, Langer R, Farokhzad OC. New frontiers in nanotechnology for cancer treatment. Urol Oncol 2008;26:74-85

57. Guler B, Demir B, Guler E, Gulec K, Yesiltepe O, Demirkol DO, Timur S. Targeting and imaging of cancer cells using nanomaterials. In: Grumezescu AM, editor. Nanobiomaterials in Medical Imaging. Oxford: Elsevier; 2016. 209-251

58. Bae KH, Chung HJ, Park TG. Nanomaterials for cancer therapy and imaging. Mol Cells 2011;31:295-302

59. Liu Q, Jin C, Wang Y, Fang X, Zhang X, Chen Z, Tan $\mathrm{W}$. Aptamer-conjugated nanomaterials for specific cancer cell recognition and targeted cancer therapy. NPG Asia Mater 2014;6. pii: e95
60. Tan WB, Jiang S, Zhang Y. Quantum-dot based nanoparticles for targeted silencing of HER2/neu gene via RNA interference. Biomaterials 2007;28:1565-1571

61. Savla R, Taratula O, Garbuzenko O, Minko T. Tumor targeted quantum dot-mucin 1 aptamer-doxorubicin conjugate for imaging and treatment of cancer. J Control Release 2011;153:16-22

62. Ruan J, Song H, Qian Q, Li C, Wang K, Bao C, Cui D. HER2 monoclonal antibody conjugated RNase-A-associated CdTe quantum dots for targeted imaging and therapy of gastric cancer. Biomaterials 2012;33:7093-7102

63. Li Y, He H, Jia X, Lu WL, Lou J, Wei Y. A dual-targeting nanocarrier based on poly(amidoamine) dendrimers conjugated with transferrin and tamoxifen for treating brain gliomas. Biomaterials 2012;33:3899-3908

64. Yang W, Cheng Y, Xu T, Wang X, Wen LP. Targeting cancer cells with biotin-dendrimer conjugates. Eur J Med Chem 2009;44:862-868

65. Montet X, Funovics M, Montet-Abou K, Weissleder R, Josephson L. Multivalent effects of RGD peptides obtained by nanoparticle display. J Med Chem 2006;49:6087-6093

66. Toma A, Otsuji E, Kuriu Y, Okamoto K, Ichikawa D, Hagiwara A, Ito H, Nishimura T, Yamagishi H. Monoclonal antibody A7-superparamagnetic iron oxide as contrast agent of MR imaging of rectal carcinoma. Br J Cancer 2005;93:131-136

67. Chanda N, Kattumuri V, Shukla R, Zambre A, Katti K, Upendran A, Kulkarni RR, Kan P, Fent GM, Casteel SW, Smith CJ, Boote E, Robertson JD, Cutler C, Lever JR, Katti KV, Kannan R. Bombesin functionalized gold nanoparticles show in vitro and in vivo cancer receptor specificity. Proc Natl Acad Sci U S A 2010;107:8760-8765

68. Patra CR, Bhattacharya R, Mukherjee P. Fabrication and functional characterization of goldnanoconjugates for potential application in ovarian cancer. J Mater Chem 2010; 20:547-554

69. Li JL, Wang L, Liu XY, Zhang ZP, Guo HC, Liu WM, Tang SH. In vitro cancer cell imaging and therapy using transferrin-conjugated gold nanoparticles. Cancer Lett 2009; 274:319-326

70. Li R, Wu R, Zhao L, Hu Z, Guo S, Pan X, Zou H. Folate and iron difunctionalized multiwall carbon nanotubes as dual-targeted drug nanocarrier to cancer cells. Carbon 2011;49:1797-1805

71. Yao HJ, Zhang YG, Sun L, Liu Y. The effect of hyaluronic acid functionalized carbon nanotubes loaded with salinomycin on gastric cancer stem cells. Biomaterials 2014;35: 9208-9223

72. Sun X, Liu Z, Welsher K, Robinson JT, Goodwin A, Zaric S, Dai H. Nano-graphene oxide for cellular imaging and drug delivery. Nano Res 2008;1:203-212

73. Laginha KM, Moase EH, Yu N, Huang A, Allen TM. Bioavailability and therapeutic efficacy of HER2 scFv-targeted liposomal doxorubicin in a murine model of HER2-overexpressing breast cancer. J Drug Target 2008; 16:605-610 
74. Chen Y, Liang H. Applications of quantum dots with upconverting luminescence in bioimaging. J Photochem Photobiol B 2014;135:23-32

75. Zhao Y, Liu S, Li Y, Jiang W, Chang Y, Pan S, Fang X, Wang YA, Wang J. Synthesis and grafting of folate-PEGPAMAM conjugates onto quantum dots for selective targeting of folate-receptor-positive tumor cells. J Colloid Interface Sci 2010;350:44-50

76. Pathakoti K, Hwang HM, Xu H, Aguilar ZP, Wang A. In vitro cytotoxicity of $\mathrm{CdSe} / \mathrm{ZnS}$ quantum dots with different surface coatings to human keratinocytes HaCaT cells. J Environ Sci (China) 2013;25:163-171

77. Hughes GA. Nanostructure-mediated drug delivery. In: Balogh LP, editor. Nanomedicine. Singapore: Pan Stanford Publishing; 2017. 47-72.

78. Aulenta F, Hayes W, Rannard S. Dendrimers: a new class of nanoscopic containers and delivery devices. Eur Polym J 2003;39:1741-1771

79. Najlah M, D'Emanuele A. Crossing cellular barriers using dendrimer nanotechnologies. Curr Opin Pharmacol 2006;6: $522-527$

80. Oliveira JM, Salgado AJ, Sousa N, Mano JF, Reis RL. Dendrimers and derivatives as a potential therapeutic tool in regenerative medicine strategies--a review. Prog Polym Sci 2010;35:1163-1194

81. Pillai O, Panchagnula R. Polymers in drug delivery. Curr Opin Chem Biol 2001;5:447-451

82. Pissuwan D, Valenzuela SM, Cortie MB. Therapeutic possibilities of plasmonically heated gold nanoparticles. Trends Biotechnol 2006;24:62-67

83. Mahmoudi M, Sant S, Wang B, Laurent S, Sen T. Superparamagnetic iron oxide nanoparticles (SPIONs): development, surface modification and applications in chemotherapy. Adv Drug Deliv Rev 2011;63:24-46

84. Kodama R. Magnetic nanoparticles. J Magn Magn Mater 1999;200:359-372

85. Neuberger T, Schöpf B, Hofmann H, Hofmann M, von Rechenberg B. Superparamagnetic nanoparticles for biomedical applications: possibilities and limitations of a new drug delivery system. J Magn Mater 2005;293:483-496

86. Syková E, Jendelová P. Migration, fate and in vivo imaging of adult stem cells in the CNS. Cell Death Differ 2007;14: 1336-1342

87. Magrez A, Kasas S, Salicio V, Pasquier N, Seo JW, Celio M, Catsicas S, Schwaller B, Forró L. Cellular toxicity of carbon-based nanomaterials. Nano Lett 2006;6:1121-1125

88. Zhang BT, Zheng X, Li HF, Lin JM. Application of carbon-based nanomaterials in sample preparation: a review. Anal Chim Acta 2013;784:1-17

89. Scida K, Stege PW, Haby G, Messina GA, García CD. Recent applications of carbon-based nanomaterials in analytical chemistry: critical review. Anal Chim Acta 2011; 691:6-17

90. Cha C, Shin SR, Annabi N, Dokmeci MR, Khademhosseini A. Carbon-based nanomaterials: multifunctional materials for biomedical engineering. ACS Nano 2013;7:2891-
2897

91. Lasic DD. Novel applications of liposomes. Trends Biotechnol 1998;16:307-321

92. Fenske DB, Chonn A, Cullis PR. Liposomal nanomedicines: an emerging field. Toxicol Pathol 2008;36:21-29

93. Lyakhovich A, Lleonart ME. Bypassing mechanisms of mitochondria-mediated cancer stem cells resistance to chemoand radiotherapy. Oxid Med Cell Longev 2016;2016: 1716341

94. Hong IS, Jang GB, Lee HY, Nam JS. Targeting cancer stem cells by using the nanoparticles. Int J Nanomedicine 2015;10:251-260

95. Abetov D, Mustapova Z, Saliev T, Bulanin D, Batyrbekov K, Gilman CP. Novel small molecule inhibitors of cancer stem cell signaling pathways. Stem Cell Rev 2015;11:909918

96. He L, Gu J, Lim LY, Yuan ZX, Mo J. Nanomedicine-mediated therapies to target breast cancer stem cells. Front Pharmacol 2016;7:313

97. Wang Z, Tan J, McConville C, Kannappan V, Tawari PE, Brown J, Ding J, Armesilla AL, Irache JM, Mei QB, Tan Y, Liu Y, Jiang W, Bian XW, Wang W. Poly lactic-co-glycolic acid controlled delivery of disulfiram to target liver cancer stem-like cells. Nanomedicine 2017;13:641-657

98. Estey T, Piatigorsky J, Lassen N, Vasiliou V. ALDH3A1: a corneal crystallin with diverse functions. Exp Eye Res 2007;84:3-12

99. Ginestier C, Hur MH, Charafe-Jauffret E, Monville F, Dutcher J, Brown M, Jacquemier J, Viens P, Kleer CG, Liu S, Schott A, Hayes D, Birnbaum D, Wicha MS, Dontu G. ALDH1 is a marker of normal and malignant human mammary stem cells and a predictor of poor clinical outcome. Cell Stem Cell 2007;1:555-567

100. Lu B, Huang X, Mo J, Zhao W. Drug delivery using nanoparticles for cancer stem-like cell targeting. Front Pharmacol 2016;7:84

101. Li D, Zhang T, Gu W, Li P, Cheng X, Tong T, Wang W. The $\mathrm{ALDHl}^{+}$subpopulation of the human NMFH-1 cell line exhibits cancer stem-like characteristics. Oncol Rep 2015;33:2291-2298

102. Liu SY, Zheng PS. High aldehyde dehydrogenase activity identifies cancer stem cells in human cervical cancer. Oncotarget 2013;4:2462-2475

103. Shao C, Sullivan JP, Girard L, Augustyn A, Yenerall P, Rodriguez-Canales J, Liu H, Behrens C, Shay JW, Wistuba II, Minna JD. Essential role of aldehyde dehydrogenase $1 \mathrm{~A} 3$ for the maintenance of non-small cell lung cancer stem cells is associated with the STAT3 pathway. Clin Cancer Res 2014;20:4154-4166

104. Yue L, Huang ZM, Fong S, Leong S, Jakowatz JG, Charruyer-Reinwald A, Wei M, Ghadially R. Targeting ALDH1 to decrease tumorigenicity, growth and metastasis of human melanoma. Melanoma Res 2015;25:138-148

105. Vira D, Basak SK, Veena MS, Wang MB, Batra RK, Srivatsan ES. Cancer stem cells, microRNAs, and therapeutic strategies including natural products. Cancer 
Metastasis Rev 2012;31:733-751

106. Yip NC, Fombon IS, Liu P, Brown S, Kannappan V, Armesilla AL, Xu B, Cassidy J, Darling JL, Wang W. Disulfiram modulated ROS-MAPK and NF $\kappa$ B pathways and targeted breast cancer cells with cancer stem cell-like properties. Br J Cancer 2011;104:1564-1574

107. Chen D, Cui QC, Yang H, Dou QP. Disulfiram, a clinically used anti-alcoholism drug and copper-binding agent, induces apoptotic cell death in breast cancer cultures and xenografts via inhibition of the proteasome activity. Cancer Res 2006;66:10425-10433

108. Kast RE, Boockvar JA, Brüning A, Cappello F, Chang WW, Cvek B, Dou QP, Duenas-Gonzalez A, Efferth T, Focosi D, Ghaffari SH, Karpel-Massler G, Ketola K, Khoshnevisan A, Keizman D, Magné N, Marosi C, McDonald K, Muñoz M, Paranjpe A, Pourgholami MH, Sardi I, Sella A, Srivenugopal KS, Tuccori M, Wang W, Wirtz CR, Halatsch ME. A conceptually new treatment approach for relapsed glioblastoma: coordinated undermining of survival paths with nine repurposed drugs (CUSP9) by the International Initiative for Accelerated Improvement of Glioblastoma Care. Oncotarget 2013;4:502-530

109. Hothi P, Martins TJ, Chen L, Deleyrolle L, Yoon JG, Reynolds B, Foltz G. High-throughput chemical screens identify disulfiram as an inhibitor of human glioblastoma stem cells. Oncotarget 2012;3:1124-1136

110. Wang W, McLeod HL, Cassidy J. Disulfiram-mediated inhibition of NF-kappaB activity enhances cytotoxicity of 5-fluorouracil in human colorectal cancer cell lines. Int $\mathrm{J}$ Cancer 2003;104:504-511

111. Guo X, Xu B, Pandey S, Goessl E, Brown J, Armesilla AL, Darling JL, Wang W. Disulfiram/copper complex inhibiting NFkappaB activity and potentiating cytotoxic effect of gemcitabine on colon and breast cancer cell lines. Cancer Lett 2010;290:104-113

112. Liu P, Brown S, Goktug T, Channathodiyil P, Kannappan V, Hugnot JP, Guichet PO, Bian X, Armesilla AL, Darling JL, Wang W. Cytotoxic effect of disulfiram/copper on human glioblastoma cell lines and ALDH-positive cancer-stem-like cells. Br J Cancer 2012;107:1488-1497

113. Zöller M. CD44: can a cancer-initiating cell profit from an abundantly expressed molecule? Nat Rev Cancer 2011;11:254-267

114. Al-Hajj M, Wicha MS, Benito-Hernandez A, Morrison SJ, Clarke MF. Prospective identification of tumorigenic breast cancer cells. Proc Natl Acad Sci U S A 2003;100: 3983-3988

115. Dalerba P, Dylla SJ, Park IK, Liu R, Wang X, Cho RW, Hoey T, Gurney A, Huang EH, Simeone DM, Shelton AA, Parmiani G, Castelli C, Clarke MF. Phenotypic characterization of human colorectal cancer stem cells. Proc Natl Acad Sci U S A 2007;104:10158-10163

116. Deonarain MP, Kousparou CA, Epenetos AA. Antibodies targeting cancer stem cells: a new paradigm in immunotherapy? MAbs 2009;1:12-25

117. Gener P, Gouveia LP, Sabat GR, de Sousa Rafael DF, Fort
NB, Arranja A, Fernández Y, Prieto RM, Ortega JS, Arango D, Abasolo I, Videira M, Schwartz S Jr. Fluorescent CSC models evidence that targeted nanomedicines improve treatment sensitivity of breast and colon cancer stem cells. Nanomedicine 2015;11:1883-1892

118. Arabi L, Badiee A, Mosaffa F, Jaafari MR. Targeting CD44 expressing cancer cells with anti-CD44 monoclonal antibody improves cellular uptake and antitumor efficacy of liposomal doxorubicin. J Control Release 2015;220:275-286

119. Aires A, Ocampo SM, Simões BM, Josefa Rodríguez M, Cadenas JF, Couleaud P, Spence K, Latorre A, Miranda R, Somoza Á, Clarke RB, Carrascosa JL, Cortajarena AL. Multifunctionalized iron oxide nanoparticles for selective drug delivery to CD44-positive cancer cells. Nanotechnology 2016;27:065103

120. Ni M, Xiong M, Zhang X, Cai G, Chen H, Zeng Q, Yu Z. Poly(lactic-co-glycolic acid) nanoparticles conjugated with CD133 aptamers for targeted salinomycin delivery to CD133+ osteosarcoma cancer stem cells. Int J Nanomedicine 2015;10:2537-2554

121. Qi X, Yu D, Jia B, Jin C, Liu X, Zhao X, Zhang G. Targeting CD133(+) laryngeal carcinoma cells with chemotherapeutic drugs and siRNA against ABCG2 mediated by thermo/pH-sensitive mesoporous silica nanoparticles. Tumour Biol 2016;37:2209-2217

122. Li Y, Zhang T. Targeting cancer stem cells by curcumin and clinical applications. Cancer Lett 2014;346:197-205

123. Lim KJ, Bisht S, Bar EE, Maitra A, Eberhart CG. A polymeric nanoparticle formulation of curcumin inhibits growth, clonogenicity and stem-like fraction in malignant brain tumors. Cancer Biol Ther 2011;11:464-473

124. Mumm JS, Kopan R. Notch signaling: from the outside in. Dev Biol 2000;228:151-165

125. Tang SN, Fu J, Nall D, Rodova M, Shankar S, Srivastava RK. Inhibition of sonic hedgehog pathway and pluripotency maintaining factors regulate human pancreatic cancer stem cell characteristics. Int J Cancer 2012;131:3040

126. Fan X, Matsui W, Khaki L, Stearns D, Chun J, Li YM, Eberhart CG. Notch pathway inhibition depletes stem-like cells and blocks engraftment in embryonal brain tumors. Cancer Res 2006;66:7445-7452

127. Mamaeva V, Rosenholm JM, Bate-Eya LT, Bergman L, Peuhu E, Duchanoy A, Fortelius LE, Landor S, Toivola DM, Lindén M, Sahlgren C. Mesoporous silica nanoparticles as drug delivery systems for targeted inhibition of Notch signaling in cancer. Mol Ther 2011;19:1538-1546

128. Mamaeva V, Niemi R, Beck M, Özliseli E, Desai D, Landor S, Gronroos T, Kronqvist P, Pettersen IK, McCormack E, Rosenholm JM, Linden M, Sahlgren C. Inhibiting notch activity in breast cancer stem cells by glucose functionalized nanoparticles carrying $\gamma$-secretase inhibitors. Mol Ther 2016;24:926-936

129. Yang ZF, Ngai P, Ho DW, Yu WC, Ng MN, Lau CK, Li ML, Tam KH, Lam CT, Poon RT, Fan ST. Identification of local and circulating cancer stem cells in human liver 
cancer. Hepatology 2008;47:919-928

130. Bakalova R, Ohba H, Zhelev Z, Ishikawa M, Baba Y. Quantum dots as photosensitizers? Nat Biotechnol 2004;22: 1360-1361

131. Ruiz i Altaba A, Sánchez P, Dahmane N. Gli and hedgehog in cancer: tumours, embryos and stem cells. Nat Rev Cancer 2002;2:361-372

132. Rubin LL, de Sauvage FJ. Targeting the Hedgehog pathway in cancer. Nat Rev Drug Discov 2006;5:1026-1033

133. Kiesslich T, Berr F, Alinger B, Kemmerling R, Pichler M, Ocker M, Neureiter D. Current status of therapeutic targeting of developmental signalling pathways in oncology. Curr Pharm Biotechnol 2012;13:2184-2220

134. Chenna V, Hu C, Pramanik D, Aftab BT, Karikari C, Campbell NR, Hong SM, Zhao M, Rudek MA, Khan SR, Rudin CM, Maitra A. A polymeric nanoparticle encapsulated small-molecule inhibitor of Hedgehog signaling (NanoHHI) bypasses secondary mutational resistance to Smoothened antagonists. Mol Cancer Ther 2012;11:165-173

135. Xu Y, Chenna V, Hu C, Sun HX, Khan M, Bai H, Yang XR, Zhu QF, Sun YF, Maitra A, Fan J, Anders RA. Polymeric nanoparticle-encapsulated hedgehog pathway inhibitor HPI-1 (NanoHHI) inhibits systemic metastases in an orthotopic model of human hepatocellular carcinoma. Clin Cancer Res 2012;18:1291-1302

136. Verma RK, Yu W, Singh SP, Shankar S, Srivastava RK. Anthothecol-encapsulated PLGA nanoparticles inhibit pancreatic cancer stem cell growth by modulating sonic hedgehog pathway. Nanomedicine 2015;11:2061-2070

137. Moses H, Barcellos-Hoff MH. TGF-beta biology in mammary development and breast cancer. Cold Spring Harb Perspect Biol 2011;3:a003277

138. Bellam N, Pasche B. Tgf-beta signaling alterations and colon cancer. Cancer Treat Res 2010;155:85-103

139. Wu K, Ding J, Chen C, Sun W, Ning BF, Wen W, Huang L, Han T, Yang W, Wang C, Li Z, Wu MC, Feng GS, Xie WF, Wang HY. Hepatic transforming growth factor beta gives rise to tumor-initiating cells and promotes liver cancer development. Hepatology 2012;56:2255-2267

140. Ischenko I, Liu J, Petrenko O, Hayman MJ. Transforming growth factor-beta signaling network regulates plasticity and lineage commitment of lung cancer cells. Cell Death Differ 2014;21:1218-1228

141. Gao J, Zhu Y, Nilsson M, Sundfeldt K. TGF- $\beta$ isoforms induce EMT independent migration of ovarian cancer cells. Cancer Cell Int 2014;14:72

142. Liu Z, Bandyopadhyay A, Nichols RW, Wang L, Hinck $\mathrm{AP}$, Wang S, Sun LZ. Blockade of autocrine TGF- $\beta$ signaling inhibits stem cell phenotype, survival, and metastasis of murine breast cancer cells. J Stem Cell Res Ther 2012;2:1-8

143. Mishra L, Shetty K, Tang Y, Stuart A, Byers SW. The role of TGF-beta and Wnt signaling in gastrointestinal stem cells and cancer. Oncogene 2005;24:5775-5789

144. Amin R, Mishra L. Liver stem cells and tgf-Beta in hepatic carcinogenesis. Gastrointest Cancer Res 2008;2(4 Suppl): S27-S30

145. Gomez-Casal R, Bhattacharya C, Ganesh N, Bailey L, Basse P, Gibson M, Epperly M, Levina V. Non-small cell lung cancer cells survived ionizing radiation treatment display cancer stem cell and epithelial-mesenchymal transition phenotypes. Mol Cancer 2013;12:94

146. Meng H, Zhao Y, Dong J, Xue M, Lin YS, Ji Z, Mai WX, Zhang $\mathrm{H}$, Chang $\mathrm{CH}$, Brinker CJ, Zink JI, Nel AE. Two-wave nanotherapy to target the stroma and optimize gemcitabine delivery to a human pancreatic cancer model in mice. ACS Nano 2013;7:10048-10065

147. Zuo ZQ, Chen KG, Yu XY, Zhao G, Shen S, Cao ZT, Luo YL, Wang YC, Wang J. Promoting tumor penetration of nanoparticles for cancer stem cell therapy by TGF- $\beta$ signaling pathway inhibition. Biomaterials 2016;82:48-59

148. Tsai YS, Chen YH, Cheng PC, Tsai HT, Shiau AL, Tzai TS, Wu CL. TGF- $\beta 1$ conjugated to gold nanoparticles results in protein conformational changes and attenuates the biological function. Small 2013;9:2119-2128

149. Singh VK, Saini A, Chandra R. The implications and future perspectives of nanomedicine for cancer stem cell targeted therapies. Front Mol Biosci 2017;4:52

150. Zhao Y, Alakhova DY, Kabanov AV. Can nanomedicines kill cancer stem cells? Adv Drug Deliv Rev 2013;65:17631783

151. Youn YS, Bae YH. Perspectives on the past, present, and future of cancer nanomedicine. Adv Drug Deliv Rev 2018; 130:3-11

152. Tabassum N, Verma V, Kumar M, Kumar A, Singh B. Nanomedicine in cancer stem cell therapy: from fringe to forefront. Cell Tissue Res 2018;374:427-438 